\title{
Efferent Neuron
}

National Cancer Institute

\section{Source}

National Cancer Institute. Efferent Neuron. NCI Thesaurus. Code C12643.

A neuron that sends impulses from the central nervous system to skeletal muscles, glands, and visceral organs. 